\title{
Nos Espaços Públicos da Cidade: Movimentos de Testemunhas e a Formação de Comunidade Moral $^{132}$
}

\section{In the City's Public Spaces: Movements of Witnesses and the Formation of Moral Community}

\author{
André Grahle \\ Professor Assistente na LMU Munique \\ Tradução: Francisco Corrêa \\ Doutorando em filosofia na UNIFESP
}

$\mathbf{F}$ sua muito aclamada e amplamente autobiográfica peça IThe Trip ["A Viagem"], o diretor e dramaturgo sírio Anis Hamdoun retrata um grupo de jovens ativistas anti-governo da cidade de Homs. Arrancados de suas vidas normais, moldados pelos problemas do cotidiano e sonhos por carreiras específicas, os amigos repentinamente se encontram em meio a protestos

132 Para citação, usar: André Grahle (2019) "In the City’s Public Spaces: Movements of Witnesses and the Formation of Moral Community", in: Emma Cox, Sam Durrant, David Farrier, Lyndsey Stonebridge, Agnes Woolley (Eds.) Refugee Imaginaries: Research Across the Humanities, Edinburgh: Edinburgh University Press. 
revolucionários, visando os objetivos mais elevados da democracia, dignidade e liberdade. É o ano de 2011, e a Primavera Árabe chegara à Síria, e o regime, cuja queda eventualmente o povo exigiria, logo responde com uma repressão brutal contra os manifestantes pacíficos. Essa repressão torna-se a guerra que conhecemos, a qual até o momento causou a morte de centenas de milhares de pessoas e deslocou metade da população síria. Como muitos naquele momento, os jovens ativistas retratados por Hamoum começam a documentar atrocidades e a ajudar a cuidar dos feridos, mas logo eles próprios tornam-se alvos.

A maior parte da peça consiste nos ativistas fornecendo, a partir de um local de exílio, seus relatos em primeira pessoa do que testemunharam por meio da experiência direta ou observação: histórias de desaparecimentos forçados, estupro, cerco e bombardeio. Entretanto, próximo ao final da peça, é revelado que o protagonista, Rami, é o único dos quatro que de fato conseguiu escapar do país. Todos os seus amigos estão mortos e, no entanto, estão presentes para ele de maneira avassaladora, através de suas vozes insculpidas em sua inquieta memória. O exílio de Rami é de intensa solidão, permeado por sentimentos de culpa, desesperança, raiva e aflição; uma solidão cuja profundidade torna-se ainda mais difícil de ser superada por ele estar preso às lembranças de seus amigos mortos. A peça parece sugerir que Rami está preso a essas memórias devido ao seu novo ambiente social, o qual o mantém confinado ao privá-lo de quaisquer meios significativos para envolver-se com suas próprias memórias. A peça se desenrola à noite e, embora não seja sequer revelado ao público em qual país ou cidade está Rami, também não há encontro humano algum entre Rami e a sociedade na qual ele se encontra. De fato, outras pessoas são aludidas apenas esquematicamente, tal como quando Rami interrompe a sua própria fala ao expressar sua intenção de encontrar um emprego em uma empresa com um chefe que permanece completamente abstrato. Parece como se a nova sociedade exercesse poder sobre Rami não apenas através de sua presença e potencial de agir contra ele, mas também através de sua falta e de suas omissões sistemáticas, sobretudo através de 
sua completa falta de uma cultura de receptividade para aquilo que está na mente de Rami.

A Viagem foi encenada diversas vezes no Teatro de Osnabrück, que estreou em 2015 no festival Spieltriebe de teatro contemporâneo. Foi lida e encenada em várias outras cidades da Alemanha, inclusive no Kammerspiele de Munique e Schaubühne de Berlim como parte de um festival maior de teatro chamado FIND. Normalmente, as encenações têm sido seguidas por discussões públicas, com Hamdoun fornecendo informações adicionais sobre o processo de produção, sua própria experiência como artista e ativista revolucionário na Síria contemporânea, os aspectos autobiográficos da peça e seu contexto político específico. Na época, a questão de uma resposta apropriada alemã e europeia às maiores crises de deslocamento desde a segunda guerra mundial já havia recebido atenção persistentemente forte nos maiores níveis da sociedade, incluindo, evidentemente, a mídia, partidos políticos, ativistas, grupos voluntários, bem como um grande número de artistas, redes culturais e instituições ${ }^{133}$. No entanto, não se pode negar que atos e expressões de solidariedade a refugiados, bem como tentativas de entender a opressão com a qual se defrontam os refugiados que têm como destino a Europa, estavam principalmente preocupados com outras injustiças que não aquelas que ocasionaram em primeiro lugar a fuga dessas pessoas ${ }^{134}$. Isso deu origem a uma imagem das agruras dos refugiados como redutíveis ao risco de atravessar o Mediterrâneo, de se defrontar com vários obstáculos na rota pelos Bálcãs ou, depois, de se defrontar com o racismo e (outras) formas de discriminação

133 Quando falo em "maior crise de deslocamento desde a Segunda Guerra Mundial", refiro-me ao que é o maior número de pessoas deslocadas desde a Segunda Guerra Mundial, de acordo com um relatório da ACNUR (2015).

134 Ver, por exemplo, o relatório da Anistia Internacional (2016) sobre desaparecimentos forçados, e o relatório da ACNUR (2016) sobre tortura como meio de extermínio. Para um relatório sobre a dimensão do uso da fome como tática de guerra, ver, por exemplo, o documento (2018) da Comissão Internacional de Investigação sobre a República Árabe Síria. Para um relatório de violência sexual e baseada em gênero, ver (2018b), documento da mesma comissão. Negação pública de crimes de guerra e escárnio de vítimas, por sua vez, ocorreu em incontáveis ocasiões. Até mesmo pesquisadores trabalhando em universidades ocidentais tem sido acusados disso (cf. Ahmad 2018). 
estrutural, incluindo, é claro, a ameaça de deportação e detenção. As injustiças que os refugiados experimentaram em seu país de origem e a luta contra elas foram frequentemente tratadas separadas e de maneira bastante insuficiente, a despeito de serem também um importante campo de solidariedade.

A Viagem pode ser vista como uma tentativa inicial de combater essa tendência predominante. Ela fornece uma compreensão básica de algumas das mais graves injustiças que afetaram um grande número de refugiados sírios que recentemente chegaram à Alemanha. No entanto, o mais crucial é a exposição desnuda do dano causado pela recusa das sociedades receptoras em envolver-se devidamente com o testemunho dos refugiados sobre tais injustiças. Ainda que em coerência elegante com esse pensamento, $A$ Viagem não induz apenas culpa em seu público, mas dá a impressão encorajadora que prestar a devida atenção aqui e agora à peça é propício à prevenção de tais danos. Tal com fica claro a partir dos perfis de mídia (cf. Meiborg, 2016; Marcus, 2016a) e das várias discussões as quais participei ao longo de um ano, não é apenas Rami que fala na total ausência de encontro humano real, também Hamoun fala à plateia através de sua peça. Além disso, as encenações e discussões contaram com a participação de sírios e não-sírios. Ocasionalmente, a encenação serviu como ponto de referência para outros sírios que recentemente haviam chegado à Alemanha, fornecendo-os uma ocasião para dirigirem-se a partes de seu novo contexto social ao dar os seus próprios testemunhos sem que tivessem de começar do zero. Um relato (Schmitt 2016) menciona um homem sírio na plateia falando sobre seu próprio tempo na prisão, sobre os gritos daqueles sendo torturados ao seu redor que ainda o assombram, bem como o destino de seu irmão mais novo, um médico do qual não se teve mais notícias desde o seu desaparecimento forçado há anos. O homem é citado como expressando sua apreciação pelo fato de que parte de sua própria experiência encontrou expressão na peça de Hamdoun. Uma série de casos semelhantes sugere que a peça indiretamente beneficiou outros sírios ao receberem, pela sociedade receptora, reconhecimento por seu sofrimento e sua persistente luta por liberdade e dignidade na Síria. 
Inicio a primeira seção deste capítulo explicando como os refugiados chegam como testemunhas de graves injustiças experimentadas em seu país de origem, sendo que alguns deles, além do mais, buscam ativamente dar seu testemunho no exílio, potencialmente formando o que denomino movimentos de testemunhas. Na segunda seção, defendo o valor desses movimentos ao fazerem uso dos espaços públicos da cidade para dirigirem seu testemunho às partes da sociedade receptora. Defendo que dar tal testemunho pode ser uma questão de insculpir uma história na consciência da cidade e de se engajar naquilo que denomino de formação de comunidade moral. Pode-se conquistar elementos da sociedade receptora, visto que eles reconhecem moralmente o sofrimento do grupo de outrem e a legitimidade de sua luta libertadora. Reconhecimento moral, por sua vez, é uma condição crucial para que alguns refugiados possam conceber uma nova sociedade como uma das quais eles possam genuinamente participar. Concluo o capítulo com algumas observações preliminares sobre o dever moral das comunidades das cidades de conceder acesso mais efetivo a espaços públicos aos movimentos de testemunhas.

\section{Testemunhas e Movimentos de Testemunhas}

Refugiados tendem a chegar como testemunhas de graves injustiças em seu país de origem. Tornaram-se tais testemunhas ao eles próprios terem-nas experimentado, ou ao observarem as experiências de outras pessoas em sua proximidade.

Há um grão de verdade conceitual na primeira reivindicação, visto que é parte do conceito do refugiado ser alguém forçado a deslocar-se, o que claramente conta como uma injustiça, e uma das graves enquanto tal. Isso por si sugere que os refugiados chegam como testemunhas de ao menos essa injustiça. Em muitos casos, entretanto, o deslocamento forçado não será o único tipo de grave de injustiça a qual os refugiados experimentaram e observaram em seu país de origem. Não ofereço aqui uma definição estrita do que torna uma injustiça grave. No entanto, podemos, fiando-se no senso comum e conhecimento geral da natureza da opressão estatal grave, terrorismo e guerra 
hoje, iniciar uma lista aberta que decerto deve incluir os males do desaparecimento forçado, tortura, estupro e violência sexual, cerco e fome, assassinato em massa, limpeza étnica e genocídio, bem como humilhação através da negação pública de tais crimes.

Assim, por exemplo, se olharmos para as provas no caso da Síria, nas quais quase todos esses crimes foram cometidos, incluindo, evidentemente, o bombardeamento de bairros civis, mas também o desaparecimento forçado de dezenas de milhares, bem como a tortura enquanto um meio daquilo que o Conselho de Direitos Humanos das Nações Unidas se refere como "extermínio", a aplicação de métodos de morte por fome como arma contra civis vivendo sob cerco, violência sexual e baseada em gênero, assim como o escárnio público das vítimas e negação ampla de tais crimes, podemos estimar a probabilidade de refugiados sírios chegarem como testemunhas de outras graves injustiças que não somente o deslocamento forçado. Da minha humilde perspectiva como um ativista envolvido em projetos de testemunho na Alemanha, país que recebeu cerca de 700.000 refugiados sírios desde o início da guerra, a proporção de refugiados afetados por essas injustiças é avassaladora. Para muitos, fugir do país certamente não era o equivalente a fugir de ataques dentro do país, e a perda de familiares e entes queridos em um conflito que continua durante o exílio é a regra e não a exceção.

Trato o registro passivo de um acontecimento como suficiente para tornar-se uma testemunha do acontecimento. Não cabe ao agente escolher tornar-se ou não uma testemunha ao menos do fato que uma certa injustiça está ocorrendo, caso a injustiça ocorra dentro do alcance perceptivo do agente. ${ }^{135}$ O lado passivo do testemunho, entretanto, é frequentemente enriquecido por um mais ativo. Testemunhas podem exercitar sua agência epistêmica. Não quero dizer agência a caminho do testemunho, como nos casos em que jornalistas cidadãos

135 O caráter passivo de testemunhar, em combinação com o fato de que testemunhar a devastação de uma pessoa pode ser em si devastador, também significa que tornar deliberadamente uma pessoa testemunha pode, tal como quando um detendo é forçado a testemunhar a tortura de outro, ferir em seu próprio direito. 
buscam injustiças a fim de documentá-las sistematicamente. ${ }^{136}$ Quero dizer que, ao dar testemunho, as testemunhas podem ir para além do registro passivo do acontecimento. ${ }^{137}$ Elas podem envolver-se com o assunto de uma forma ou outra e em graus variados. Então, por exemplo, detentos aprisionados por um regime contrário à lei podem tomar parte em (auto-)observação meticulosa como maneira de tentar compreender em maiores detalhes a natureza da injustiça e a experiência deles desta. $\mathrm{O}$ registro pode ser seguido de perto aqui por tentativas de (ativamente) analisar aquilo que é (passivamente) registrado. ${ }^{138}$ Além disso, ao testemunhar, as pessoas às vezes engajam-se de maneira criativa com o material entregue por sua percepção. $O$ talentoso pintor sírio Najah al-Bukai, que retrata sua memória pessoal de suas experiências de tortura em centros de detenção sírios, enfatiza que se recusou a aceitar a sujeição passiva à percepção do horror diante dele: "O tempo todo em que estive no inferno, tentei não ver pesadelos. Em vez disso, forcei-me a ver lindos sonhos." ${ }^{139}$ Pode ser possível entender isso como uma questão de assumir ativamente o controle sobre o pensamento

$136 \quad$ Há um elo entre o testemunho e a responsabilidade, o qual também destaca a ambivalência no caso dos perpetradores utilizarem o testemunho prestado por alguém com a intenção de prejudicá-los. Pode ser arriscado aos perpetradores usarem essa arma (cf. fn. 3).

137 Repare que eu digo apenas "frequentemente" aqui. Isso deixa em aberto a possibilidade de casos nos quais o testemunho é amplamente confinado ao elemento passivo de registrar que uma injustiça ocorreu a si mesmo ou a outros, mas também permite casos nos quais o impacto de um evento traumático impede que as pessoas o registrem adequadamente..

138 Jean Améry (1980: 39) descreve o momento brevemente após um episódio de tortura como equipado com "o desejo de articular a experiência [de tortura] intelectualmente, imediatamente, in loco, sem perder o mínimo de tempo". 139 O tipo de arte que emerge da memória de Al-Bukai, embora claramente dirigida por uma percepção onírica, nem sequer transfigura a realidade. Em vez disso, deixa claro para os que estão de fora o grau incompreensível de devastação por trás dos bastidores, ao dar origem ao pensamento de que "ainda não vi a realidade, mas o que vejo é aterrorizante. Se este é um sonho, então como há de ser a realidade? “. Agora vivendo no exílio, Al-Bukai viaja pela França em um esforço para aumentar a conscientização sobre as condições nas masmorras de tortura na Síria. A citação no parágrafo acima é do artigo de Aida Alami (2018) sobre o trabalho de Al-Bukai, publicado no The New York Times. 
imaginação a fim de alterar o modo de experimentar aquilo que não se pode evitar registrar.. ${ }^{140}$

Outra observação diz respeito ao contexto mais amplo das injustiças testemunhadas. O contexto pode impactar a maneira através da qual as injustiças são em primeiro lugar experimentadas, o que posteriormente pode se refletir no testemunho comunicado a outrem. Mais importante ainda é notar o fato que as injustiças frequentemente são respostas a atos de resistência justa a outras injustiças, tal como quando os ativistas são detidos e torturados em resposta a violações das leis que impedem a liberdade de expressão e a reunião pacífica. Frequentemente, o significado da ordem dos eventos é refletido na experiência e no testemunho. Afirmações frequentes como "fomos bombardeados apenas porque pedimos um pouco de liberdade" ou "fui torturado, mas ao menos jamais obedeci" capturam bem isso. A primeira pode ser lida enquanto expressão do julgamento da testemunha sobre aqueles culpados de cometer a injustiça como algo especialmente infame, ao passo que a segunda pode ser entendida como expressão de um orgulho reconfortante, representando a própria agência em um contexto mais amplo de luta política. Perceber essas nuances é importante para qualquer potencial receptor do testemunho quando se trata de conduzir uma resposta apropriada ao testemunho que é ouvido. Voltaremos a isso.

Agora, deliberadamente coloco meu foco nos refugiados enquanto testemunhas, embora decerto haja muitas testemunhas de graves injustiças ligadas aos mesmos casos de opressão, ou ligados à mesma luta, que não sofreram deslocamento até agora, ou para os quais fugir, por enquanto, simplesmente não é uma opção. Alguns decidem continuar com sua luta política dentro do país, aconteça o que acontecer. Outros fugiriam imediatamente se lhes fosse possível. Testemunhas podem ainda estar em prisões, e ouvimos todos os dias sobre detentos que morrem sob tortura. No entanto, o exílio merece atenção como um local especificamente para os refugiados testemunhem, e penso que mais deveria ser dito sobre o porquê disso acontecer

$140 \quad$ Ibid. 
e como o desejo de testemunhar - comunicar o testemunho deveria ser mais bem facilitado pelas sociedades receptoras.

Eu gostaria de fazer a distinção entre dois tipos de testemunho. Primeiro, há aquilo que chamo meramente de testemunhas nominais, que adquiriram conhecimento por meio da experiência direta e da observação atenta de graves injustiças em seu país de origem, mas que atualmente não desejam dar testemunho e, portanto, não buscam oportunidades para testemunhar no exílio (mas talvez se envolvam em práticas de esquecimento, supressão, distração ou memorização pessoal). Em segundo, há aquilo que chamo de testemunhas que se auto-identificam como tais, que adquiriram conhecimento através de experiência direta e observação próxima de injustiças graves em seu país de origem, e que realmente tem desejo de dar o seu testemunho no exílio. Esse desejo pode diferir em força. Pode ser fraco ou forte; na verdade, às vezes tão forte a ponto de se apresentar à pessoa como um sentimento de que ela deve dar o seu testemunho. ${ }^{141}$ Pessoas com desejo suficientemente forte ativamente aproveitam, buscam ou ao menos efetivamente tem a esperança de oportunidades de dar o seu testemunho no exílio. Quando emprego o termo "testemunha" de maneira não especificada neste artigo, significa a testemunha que se auto-identifica como tal ${ }^{142}$.

Embora a presença de testemunhas seja de relevância ética específica para a sociedade receptora, esta não é necessariamente o local no qual nascem as testemunhas. Assim, por exemplo, a perspectiva de dar testemunho após a fuga - ou

\footnotetext{
$141 \quad$ cf. Frankfurt (1982: 263)

142 O fenômeno das testemunhas serem dotadas de um forte desejo de testemunhar não se limita, evidentemente, ao contexto recente da chegada dos refugiados. Primo Levi (2001: 162), por exemplo, mencionou "uma necessidade, uma necessidade fisiológica de se libertar da minha experiência contando a história". Deve-se notar, além disso, que o desejo de dar testemunho pode coexistir com um número de desejos contrariantes de não se dar testemunho devido a um senso da impossibilidade de comunicar a dimensão do que aconteceu, ou porque rememorar um testemunho é antecipado como algo extremamente doloroso (cf. Oliver, 20120: 102). Pode haver muitos obstáculos ao prestar testemunho, cada qual merece exame cuidadoso, mas essa discussão iria para além do escopo deste capítulo.
} 
contar ao mundo o que aconteceu aqui - podem desempenhar um papel central como uma fonte motivacional e justificadora para alguns lutarem por sua própria sobrevivência ${ }^{143}$. O desejo de testemunhar pode até figurar como uma razão por trás da fuga, pois a fuga de uma situação - tal como tortura na prisão - frequentemente há de ser seguida pelo ato de deixar a região ou país, a fim de evitar repetidas detenções ou outros tipos de agressão e / ou garantir a sobrevivência como uma condição para dar testemunho.

Nos casos de deslocamento em massa, movimentos maiores de refugiados que chegam a países (ou outros lugares) podem dar origem a movimentos de testemunhas. Emprego esse termo para me referir ao fenômeno de um grande número de testemunhas que começam a testemunhar sob novas condições socioespaciais, dirigindo-se a partes da sociedade receptora com o seu testemunho. Não penso que devamos fazer disso uma exigência conceitual para que os movimentos de testemunhas mostrem muita unidade, especialmente nos primeiros anos após a suas chegadas. Assim, a maneira a qual emprego o termo "movimento" aqui permite um fenômeno social dotado de uma natureza em grande parte sumativa. As testemunhas podem ser entidades de uma estrutura na maior parte não-organizada, consistindo meramente em indivíduos frouxamente conectados que compartilham mais ou menos do mesmo destino, que sofreram (às vezes ainda sofrem) e lutaram contra (às vezes ainda lutam contra) as mesmas injustiças, tal como a opressão pela mesma ditadura. No entanto, por causa da unidade da fonte da injustiça e do alvo da luta de cada, movimentos de testemunhas podem demonstrar um grande grau de concordância no sentido em que elas avaliam essas injustiças, de modo que, embora as testemunhas não falem necessariamente com a mesma voz ou não tenham organizado uma forma coordenada de falar, elas ainda assim podem ser reconhecidas como parte da mesma formação fragmentária, amplificando as vozes umas das outras. Testemunhas sírias na Alemanha que compartilham a experiência de terem sido afetadas de uma for-

$143 \quad$ Escutei versões disso mais de uma vez em conversas com refugiados recém-chegados na Europa. Ver também Laub (1992: 78). 
ma ou outra pela opressão do regime de Assad formam isso, um movimento de testemunhas associado de maneira meramente frouxa (mas bastante visível em sua soma).

\section{Diringindo-se à Sociedade Receptora: Espaços Pú- blicos nas Cidades}

Grosso modo, os movimentos de testemunhas têm dois locais para dirigir o seu testemunho aos membros da sociedade receptora. Primeiramente, há as relações pessoais, as quais podem ser formadas entre os recém-chegados e membros há muito da sociedade receptora. Assim, por exemplo, entre o vasto número de cidadãos que se voluntariou em contextos de ajuda a refugiados durante a atual crise de deslocamento, era longe de ser incomum que tivessem testemunhos dirigidos a si. Isso frequentemente permanece no nível do breve encontro, mas pode se desenvolver em uma relação mais sólida, tal como a amizade. Um bom amigo é, entre outras coisas, alguém que ao menos tenta ser um bom ouvinte, o que inclui a disposição para escutar o testemunho. Além disso, há um tipo distinto de relação pessoal que é mais centralmente constituído por práticas de dar e receber testemunho. A natureza exata dessas relações, as quais denomino relações de testemunho, é complicada e merece análise filosófica separada, o que eu forneço em outro lugar (Grahle, MS).

Entretanto, o que pode se dizer aqui é que a escuta virtuosa nas relações de testemunho pode figurar como uma importante fonte de reconhecimento moral tanto para o sofrimento da testemunha como para a legitimidade de sua luta libertadora. No longo prazo, relações de testemunho podem dar origem a um forte vínculo moral entre o ouvinte e a testemunha, vínculo este improvável de surgir em qualquer outro ambiente social menos íntimo, e que pode impor responsabilidades especiais ao ouvinte para que este ofereça sua solidariedade política. Além disso, o que é distinto sobre relações de testemunha e o caráter do testemunho em outras relações pessoais é o potencial de tratar o testemunho como confidencial. Essa é uma das razões pelas quais algumas testemunhas identificadas podem escolher 
relacionamentos pessoais naquele momento em vez de qualquer outro ambiente social. Dar testemunho frequentemente é acompanhado do risco à própria segurança, bem como a de família e amigos (cg. Margalit, 2004: 150). Que a testemunha opere no exílio não necessariamente importa a esse respeito. Pois o status legal da testemunha pode não ser claro, e o medo de ser deportada de volta para os braços dos perpetradores pode ser justificado. Além disso, parentes e entes queridos que ainda estejam no país podem se tornar alvo de retaliação no lugar da testemunha que fala no exterior. Nem toda testemunha está, portanto, em posição de testemunhar sobre os crimes de um regime ainda em vigor .em qualquer lugar menos confidencial do que em uma relação pessoal guiada pela confiança mútua.

Dito isso, para além das relações pessoais, há um secundo local no qual as testemunhas podem dar o seu testemunho. É o foco deste capítulo: espaços públicos e semipúblicos, muitos dos quais podem ser encontrados em cidades modernas. Decerto, o testemunho público não se limita ao domínio dos espaços (semi-)públicos. Assim, por exemplo, com o passar do tempo, há uma quantidade crescente de literatura escrita ou que dá voz a testemunhas que vivem no exílio (por exemplo, Yazbek 2015, Le Caisne 2015, Eid 2018, Pearlman 2017, al-Haj Saleh 2017, Hisham / Crabapple 2018), e relatos de testemunhas regularmente publicados em jornais e apresentados na televisão para públicos que vão para além de qualquer cidade específica. No entanto, continua sendo o caso de que nas cidades temos bibliotecas, teatros, cinemas, escolas, universidades, museus e outros locais de exposições, parques e feiras. Além disso, temos uma variedade de redes culturais, grupos políticos e grupos de voluntários, alguns dos quais podem ser acolhedores para as testemunhas. Quaisquer desses podem fornecer às testemunhas infraestruturas e outros recursos a fim de ajudá-los a fazer suas vozes serem ouvidas, especialmente logo após a chegada das testemunhas, enquanto elas não podem ainda contar com seus próprios recursos. 
Mas qual, senão outro, seria o objetivo de testemunhar publicamente fazendo uso dos vários espaços públicos que as cidades têm para oferecer? Como dito acima, apenas relações pessoais podem tratar o testemunho dado pelas testemunhas de maneira confidencial, e podemos acrescentar ainda que relações pessoais também figuram como uma importante fonte de reconhecimento moral. Isso parece sugerir que o lugar para dar testemunho deva estar apenas nas relações pessoais. Além disso, poderia ser dito que, se tais espaços públicos como teatros não são utilizados para propósitos de entretenimento, que eles podem, na melhor das hipóteses, servir ao interesse geral de certos grupos em informar-se, incluindo informar-se sobre questões políticas ao redor do mundo, enquanto frequentemente selecionam cuidadosamente para si aquilo que querem ouvir.. Isso levanta a questão de saber se as testemunhas que operam nos espaços públicos das cidades não são necessariamente reduzidas a um papel instrumental de uma fonte epistêmica que atende aos interesses dos moradores urbanos de longa data que habitualmente frequentam esses espaços em seu tempo livre. Aqueles que pensam que o testemunho público possa ser importante devem, portanto, apresentar um bom argumento que mostre que as testemunhas podem ser tratadas como fins em si mesmas e, mais importante, que elas próprias podem ganhar algo de importância moral para si ao relatar sua história a outros em público. Sou cético que seja possível fazer essa defesa de todos os contextos nos quais as testemunhas atualmente têm voz. Entretanto, minha discussão inicial de $A$ Viagem já sugere que há pelo menos o potencial para que práticas de testemunho público façam um bem no sentido exigido. Frequentemente, o prospecto de ter tal bem realizado em determinado espaço público pode ser suficiente para que as testemunhas tornem-se ativas, desde que, é claro, tenham acesso a tal espaço.

Penso que podemos entender melhor isso se prestarmos atenção cuidadosa ao fato de que o reconhecimento moral do sofrimento moral de alguém e da luta justa possui muitas camadas. Faz diferença se alguém recebe tal reconhecimento como um indivíduo face a face de outro indivíduo com o qual ele possui algum tipo de relacionamento pessoal, ou se ele re- 
cebe tal reconhecimento enquanto um grupo vindo de um contexto social mais amplo do que aquele no qual ele agora está incluso. Talvez o tipo de reconhecimento que se possa ganhar de relacionamentos pessoais possua alguma profundidade. Por exemplo, ele pode prover segurança emocional e ter uma maior chance de ser visto como a pessoa que se é, e tais coisas não podem ser providas da mesma maneira por um encontro em espaço público. E, entretanto, pode-se ainda ter um amigo muito bom ou estar em uma relação de testemunha muito boa e ainda assim sofrer de falta de reconhecimento moral em um nível social mais amplo. Há algo bom em si em seu próprio direito em receber reconhecimento moral no nível social. Em outras palavras, há algo de bom nesse ato de dar testemunho em virtude de sê-lo feito publicamente.

Avishai Margalit (2002: 155) atribui à figura que ele se refere como "testemunha moral", uma pessoa que tem conhecimento-por-contato [knowledge-by-acquaintance] do sofrimento infligido por eles por um regime maligno, o que ele descreve como uma "esperança bastante sóbria", nomeadamente a esperança "de que, em outro lugar ou outro tempo existe, ou então existirá, uma comunidade moral que irá escutar o seu testemunho" ${ }^{144}$. Uma ideia um pouco mais ambiciosa, parece-me, manifesta-se na maneira como os movimentos de testemunhas dirigem-se à sociedade receptora animando os espaços públicos nas cidades nas quais as testemunhas chegam. O que podemos frequentemente ver aqui é o poder das testemunhas de construir algum tipo de comunidade moral, por mais fragmentada que esta última provavelmente permanecerá. Dirigir-se às partes da sociedade receptora com o seu testemunho figura como meio de atingir tal objetivo no aqui e no agora. Trata-se de um projeto que depende menos da esperança e de uma atitude de espera, mas que possui um caráter decididamente "presentista”, manifestando algum grau admirável de confiança no poder da própria ação da testemunha, o ato de testemunhar que invoca o reconhecimento moral de pessoas que frequentemente

144 Acredito que a noção de Margalit de testemunha moral é, em alguns outros aspectos, desnecessariamente estreita, mas isso não importa em relação aos meus argumentos aqui. 
compartilham muito pouco da experiência da testemunha, mas que podem compartilhar da convicção de que o que ocorreu à testemunha - tortura ou quaisquer das graves injustiças acima listadas - é profundamente errado, e que é justificado resistir de alguma maneira a qualquer instância que comete tais injustiças contra outrem.

Uso o termo "comunidade moral" aqui de maneira meramente experimental como um nome para a realização do reconhecimento moral daqueles que sofrem e da luta justa de um grupo por um contexto social que se estende a esse próprio grupo. Tal como Margaret Urban Walker defendeu, a negação do reconhecimento moral de uma ofensa primária pode contar como uma forma de causar dano em seu próprio direito, o que diminuiu os prospectos de uma reparação moral (Walker, 2006: 34ff), e pode ter um impacto similar de ainda piorar a situação caso a testemunha tenha de viver exclusivamente ao redor de pessoas que negam a justiça da sua luta libertadora (em parte porque isso implica em uma negação do sofrimento). Assim, refugiados recém-chegados frequentemente atribuem significância particular à perspectiva de receber reconhecimento moral não apenas de qualquer um, mas especificamente da sociedade receptora na qual eles ainda hão de encontrar seu lugar. Algumas testemunhas podem considerar reconhecimento moral em uma escala social mais ampla como sendo uma condição para tornar-se genuinamente parte da nova sociedade em primeiro lugar. Devemos ser capazes de entender isso mesmo se não somos afetados por injustiças similares. Uma sociedade que permanece completamente ignorante do sofrimento e luta do grupo de outrem não pode tornar-se a própria sociedade dele. Embora possa ser aceitável para alguns viver dessa maneira temporariamente, o desejo por reconhecimento moral aumenta quanto menos provável é a perspectiva de se retornar em breve ao seu país de origem ${ }^{145}$.

Já que os espaços públicos no momento de chegada de um grupo de testemunhas são principalmente habitados por certos elementos da sociedade receptora, trata-se de locais

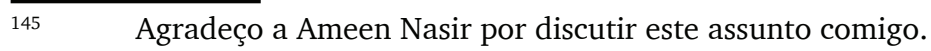


atraentes para movimentos de testemunha operar. Em certo nível básico, esses locais simplesmente oferecem uma oportunidade de formar novas relações. Na verdade, a razão pela qual os dois locais - relações pessoais e espaços públicos - figuram como fontes de reconhecimento moral é porque, precisamente, ambos são estruturalmente sobre encontro e direcionamento mútuo, o que é a condição para que ocorra qualquer tipo de reconhecimento moral. Em espaços públicos, o público pode também (diferentemente, por exemplo, do público leitor de um jornal) apresentar-se, em seu papel de bom ouvinte, de maneira até certo ponto visível à testemunha. Pense em uma mesa de conversa na qual falam testemunhas. Os rostos dos ouvintes frequentemente podem ser vistos, ao passo que expressões faciais, como as de tristeza e perplexidade ao ouvir o sofrimento da testemunha, refletem de volta à testemunha que algo daquilo que se tenta transmitir através do testemunho tenha sido apropriadamente recebido. O processo do público respondendo à testemunha que ele compreende algo daquela dor já constitui, em si, reconhecimento moral.

Ademais, enquanto muitas pessoas hesitam expressar sentimentos de tristeza em público da mesma maneira que elas estão mais prontas a fazê-lo em relacionamentos pessoais (especialmente choro), espaços públicos podem ajudá-las a dar alguma ênfase nas emoções mais positivas que podem ser tão importantes quanto aquelas outras em qualquer processo de reconhecimento moral. Tal como dito acima, o testemunho de injustiças frequentemente inclui testemunho em um contexto de resistência. "Eles me torturaram, mas ao menos nunca obedeci" pode ser ouvido como uma expressão de orgulho. Uma resposta de admiração por parte do público compartilharia com o orgulho da testemunha o mesmo objeto intencional (a força da testemunha na recusa a obedecer). Essas expressões de admiração podem ser uma forma importante de reconforto no que diz respeito à adequação do orgulho da testemunha, em momentos em que esta pode estar simultaneamente passando por todos os tipos de auto-escrutínio de emoções também, in- 
cluindo vergonha e culpa ${ }^{146}$. Admiração pela resistência do self da testemunha pode ser uma forma de reconhecimento moral tão importante quanto o reconhecimento do sofrimento através da resposta de compreensão do ouvinte. Uma dieta unilateral, isto é, uma fala na qual o ouvinte apenas demonstra compreensão, pode, na pior das hipóteses, ter efeitos sobre a testemunha que aumentam a sua vitimização.

Dar testemunho em público pode ter outro efeito valioso que vai além do bem que é potencialmente realizado entre as testemunhas e seu público direto. Em relações pessoais que tratam o testemunho confidencialmente, a prática de dar testemunho tende a afetar apenas aqueles que são parte da relação. Em contraste, dar testemunho em público conta como uma forma de espalhar a palavra, o que pode ser uma consequência desejável e, como tal, uma que pode ser visada pela testemunha, a despeito do risco que isso pode incorrer sobre ela. Outras pessoas que não participaram do mesmo evento podem ouvir sobre o testemunho através de relatos orais, ao passo que jornalistas podem relatá-lo. Mesmo onde não é o testemunho enquanto tal que é disseminado, pode ser valioso em si o mero fato de um grande número de habitantes da cidade repetidamente ouvir ou ler sobre os acontecimentos que envolvem testemunhas de determinado grupo. Isso pode ajudar um grupo mais amplo a adquirir alguma humildade, de modo a pelo menos abster-se de julgar, e talvez para, além disso, antecipar a real possibilidade de que a história de um grupo é de significância moral profunda. Talvez o bem que os movimentos de testemunhas buscam contribua para a criação de uma forma de memória social de que ao menos alguns segmentos da cidade possam ser dotados. Pode haver algo de libertador na criação de tal memória social, visto que esta vem com o potencial de libertar os indivíduos da exigência permanente de participar das atividades cognitivas e emocionais da rememoração de uma história por eles próprios.

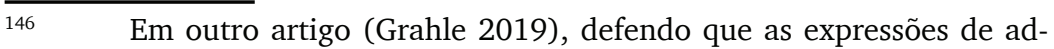
miração justificada por um agente podem contar como formas de apoio ao agente, incluindo aquilo que chamo de suporte epistêmico, similar ao fenômeno acima.
} 
Tal como diz Hamdoun, "as histórias da guerra têm de ser contadas. Somente depois se pode focar em outras coisas" ${ }^{147}$.

Por fim, a construção de uma comunidade moral através do testemunho em vários espaços públicos idealmente informa a agenda de grupos políticos, principalmente de grupos de apoio aos refugiados. Estando envolvido em contextos de ativistas e voluntários em uma cidade alemã à qual a maioria dos refugiados sírios agora morando no país chegou, tenho a impressão que parte da experiência daqueles cidadãos não-sírios, na maior parte cidadãos do estado alemão, no meu contexto imediato, passou por uma ampliação sistemática de perspectiva através do recebimento de testemunho realizado pelas testemunhas em falas em eventos públicos organizados por sua iniciativa. Para nós, foi a UE que deixou as pessoas se afogarem no Mediterrâneo, mas para os refugiados sírios também foi - às vezes principalmente - mais um crime de Assad, o de empurrar pessoas inocentes ao mar, sabendo que muitas delas morreriam. Sendo a maioria dominante nesse encontro, com os recursos materiais de mídia e redes políticas que permitem que nossa narrativa domine, demorou-nos algum tempo para perceber a urgência de juntar ambas as perspectivas. Foram as testemunhas que tiveram a ideia de organizar mesas de conversa públicas e eventos de solidariedade, na qual elas dariam os seus relatos em primeira mão das injustiças e da sua luta em seu próprio país. Foi uma conquista delas o fato de que ao menos alguns de nós começamos a perceber que ou nós nos tornaríamos acessíveis ao chamado delas por solidariedade, ou nos tornaríamos culpados de cometer mais uma forma de injustiça contra elas.

Essa injustiça secundária, que consiste em nós unilateralmente determinando quais injustiças primárias devem ser abordadas em campanha política, deve ser levada muito mais a sério por ativistas e voluntários. "Solidariedade com refugiados" tornou-se um slogan vazio se a perspectiva dos refugiados é sistematicamente ignorada porque já se decidiu quais são as metas enquanto grupo. Ao invés disso, devemos ver teste$147 \quad$ Esta é a minha tradução de uma citação encontrada em Marcus (2016b), incorporada com a renovada aprovação de Hamdoun. 
munho público como uma chance de redistribuir o poder de determinar urgência política. Não quero dizer que as agendas atualmente estabelecidas não atacam profundas injustiças que afetam refugiados. Decerto muitas delas atacam. A atitude resultante de encontros públicos com testemunhas deve ser uma de abrir-se à possibilidade de que as agendas já estabelecidas podem ser ampliadas dada a chegada de certos grupos de refugiados. Eles podem achar importante receber alguma forma de solidariedade por suas lutas contra injustiças graves ocorrendo em seus países natais também.

Por fim, a questão da prática correta da solidariedade é, evidentemente, muito mais complexa. Se a solidariedade supostamente tem de ser mais que meramente expressiva, ela tem que abordar a relação entre movimentos de testemunhas e o estado. Defendi em outro lugar que os estados das sociedades receptoras devem aos grupos de refugiado vivendo em seu território algum grau de assistência em superar severas injustiças em seus países natais (Grahle, 2017). A solidariedade entre movimentos de testemunhas e redes estabelecidas de apoio a refugiados, mas também entre outros grupos públicos, jornalistas, políticos, etc., podem chegar a pressionar o estado a assumir sua responsabilidade nesse sentido, por exemplo, protestando contra a inatividade do estado.

A pressão pública pode ser eficaz. Enquanto um Tribunal Penal Internacional é, no caso da Síria, atualmente irrealista, alguns Estados como a Alemanha e Espanha aderem ao princípio da jurisdição universal, que permite o julgamento de crimes de guerra e crimes contra a humanidade cometidos em outro território (Kaleck/ Kroker, 2018). Juntamente com o Centro Europeu de Direitos Humanos e Constitucionais (CEDHC), uma ONG sediada em Berlim, os advogados sírios e ex-presos políticos Mazen Darwish e Anwar al-Bunni apresentaram um relatório contra seis membros de alto escalão do regime sírio, com base em testemunhos de testemunhas sírias que vivem agora na Alemanha. No momento da escrita, a mais alta corte da Alemanha já decidiu aceitar o caso e emitiu um mandado de prisão internacional contra Jamil Hassan, membro do alto esca- 
lão do regime de Assad e supostamente cúmplice do extermínio de milhares de pessoas nas prisões. Além disso, dois ex-oficiais do serviço secreto do governo sírio foram presos na Alemanha sob alegações de, entre outras coisas, participarem de crimes contra a humanidade em conexão com a tortura. ${ }^{148}$

Antes da decisão de aceitar o caso, apelos públicos para que tal passo fosse dado foram frequentes e claramente audíveis. Partes do público, além do mais, acompanham os desenvolvimentos com maior atenção agora. O documentário de Tina Fuchs, Zeugen gegen Assad (Testemunhas contra Assad), transmitido pela maior emissora de televisão pública da Alemanha, $\mathrm{ARD}$, apresentou algumas das testemunhas falando sobre as experiências delas sob Assad e a motivação delas para continuar lutando por justiça no exílio ${ }^{149}$. Todo o projeto é um exemplo de uma comunidade moral nova, ampliada, que se estende para além das expressões mais básicas do reconhecimento moral na tentativa de fazer a diferença em termos políticos e jurídicos.

\section{Considerações finais: Outra razão para as cidades serem abertas}

A significância moral dos bens a serem realizados ao dar testemunho nos espaços públicos da cidade sugere fortemente que a identificação de testemunhas pode, na verdade, ter um direito moral de obter acesso a esses espaços públicos. Correspondentemente, pode-se argumentar que a sociedade receptora, incluindo o estado, tem o dever de fornecer as condições estruturais sob as quais movimentos de testemunhas podem operar de maneira suficientemente livre, evitando interferências e organizando espaços públicos nas cidades. Essas reivindicações necessitariam de mais argumentos filosóficos, mas são suficientemente plausíveis para terminar este artigo com algumas breves considerações sobre elas.

\footnotetext{
$\overline{148 \quad \text { Connoly }}$ (2019)

149 O filme também esteve temporiamente disponível com legendas em árabe no website da emissora.
} 
A ideia não é que membros da sociedade receptora tenham o dever de buscar testemunhas e convencê-las a falar. Claramente, isso seria paternalista: equivaleria a uma comunidade moral apropriar-se das testemunhas, em vez de dar às testemunhas uma oportunidade de formar sua própria comunidade moral no exílio. As pessoas devem ser livres para determinar quando e como dirigir-se à nova sociedade com seu testemunho. Dito isto, o dever de conceder acesso a espaços públicos não é menos exigente. Seria, no mínimo, o de proibir a segregação forçada que impede as testemunhas de participarem da vida na cidade, o que, por sua vez, as impede de encontrar membros da sociedade que as acolhe. Portanto, o valor de poder dirigir-se à sociedade receptora com o testemunho de alguém estabelece mais um argumento contra o status quo de acomodar ou, na pior das hipóteses, aprisionar refugiados em campos ou áreas remotas da cidade. Além disso, compartilhar o espaço público exige mais do que acabar diretamente com tendências excludentes, tais como a segregação geográfica. Requer um esforço social: arranjos positivos de compartilhamento de recursos materiais, tempo e esforço organizacional de maneiras mutuamente respeitosas.

Além disso, é importante notar que os espaços públicos aqui só podem cumprir seu propósito para as testemunhas se forem animados. Mais precisamente, devem ser espaços nos quis as pessoas participam das atividades umas das outras de maneiras mutuamente benéficas. Somente sob a condição de testemunhas recebendo uma quantidade do tipo correto de atenção que o reconhecimento moral é possível. Se o dever da sociedade receptora é o de conceder às testemunhas acesso a esse complexo de espaços públicos bons e animados, cumprir com esse dever pode exigir um esforço significativo para melhorar as competências sociais da escuta virtuosa. Questões sobre como ouvir adequadamente as testemunhas em um determinado contexto; como evitar a reprodução de injustiças epistêmicas, ao continuamente basear-se a escuta de outrem em preconceitos que impedem de conceder suficiente credibilidade às testemunhas); e que tipos de emoções devem ser 
cultivadas ao escutar as testemunhas (Grahle, MS) tornam-se relevantes aqui.

Ademais, há a questão de como evitar formas de silenciamento, algumas das quais não necessitam de envolvimento em censura direta ou exclusão explícita de testemunhas de mesas de conversa e similares. Rae Langton (1993: 315), por exemplo, defende que o simples fato de ser intimidado ou acreditar que ninguém irá ouvir mesmo pode fazer com que um grupo impotente permaneça em silêncio. Uma forma mais sutil de silenciamento ocorre quando as testemunhas se sentem pressionadas a reter a voz sobre certos assuntos, mas encorajadas a falar de outros. Testemunhas sírias que têm conhecimento da experiência das tiranias tanto do regime de Assad como do Estado Islâmico ainda tinham razões para temer a suspeição de um público ignorante, suspeição segundo a qual o testemunho sobre sua experiência do primeiro implica em alguma preferência pelo segundo. É desnecessário dizer que tornar-se alvo de tal suspeita pode ser extremamente arriscado para os refugiados. Isso pode levá-los a dar testemunho apenas dos crimes do Estado Islâmico, com o efeito de serem silenciados enquanto testemunhas dos crimes do regime de Assad. Esses casos podem ser entendidos como exemplos do que Kristie Dotson (2011: 244) chamou de sufocação de testemunho, que é "o truncamento do testemunho de outrem a fim de garantir que o depoimento contenha apenas conteúdo para o qual o público demonstra competência de testemunho".

O propósito deste artigo foi de chamar alguma atenção para o status geral dos refugiados como testemunhas e apontar alguns aspectos centrais do bem de dar o testemunho em espaços públicos. Defendi que esse bem consiste na perspectiva de formar alguma forma de comunidade moral através do chamamento de partes da sociedade receptora para que ofereçam algum grau de reconhecimento moral para o sofrimento de outrem e a justiça de sua luta libertadora. Também sugeri que o ato de dar testemunho em público pode ser uma maneira de insculpir a história de alguém na consciência da nova cidade dessa pessoa. Isso pode ser uma contribuição à construção de 
algum tipo de memória social. Por fim, defendi que a prática de dar testemunho pode impedir que grupos de apoio a refugiados cometam as injustiças secundárias de, unilateralmente, determinar contra quais injustiças primárias se deve lutar. Grupos de apoio a refugiados devem manter suas portas abertas e estarem prontos a ajustar suas agendas políticas anteriormente estabelecidas de acordo com as necessidades comunicadas por refugiados recém-chegados ${ }^{150}$.

\section{Referências:}

Ahmad, Muhammad Idrees (2018) "Syria: on academic freedom and responsibility", in: Open Democracy, April 26, disponível em: https://www.opendemocracy. net/north-africa-west-asia/muhammad-idrees-ahmad/ syria-on-academic-freedom-and-responsibility

Alami, Aida (2018) "Haunted by Memories of Syrian Torture, Saved by Art", in: The New York Times, Feb 2, disponível em: https://www.

$150 \quad$ Sou grato aos públicos filosóficos nas universidades de Osnabrück, York, Göttingen, Bochum, Bielefeld, UCD, HU Berlim e LMU Munique, por valiosas discussões de diferentes partes deste artigo. Mais importante, no entanto, gostaria de agradecer a Anis Hamdoun por ter discutido sua peça The Trip comigo em várias ocasiões, bem como por me fornecer o manuscrito em um estágio inicial. Além disso, beneficiei-me da discussão com os atores da peça teatral no Theatre Osnabrück no verão de 2015 e gostaria de agradecer a Maria Schneider por ter me convidado. O termo 'movimento de testemunhas' tem origem no título de uma mesa sobre testemunhos artísticos que eu coorganizei com Ma'an Mouslli para o Goethe-Institut de Damasco em exílio, uma série maior de eventos que ocorreram em Berlim 2016. Gostaria de agradecer a Ulrike Gasser e Marina May pelo convite, bem como aos participantes de nossa mesa, Zaina Erhaim, Zainab Alsawah, Nawar Bulbul, Sana Yazigi e Ma'an Mouslli pelo que eu experimentei como uma discussão muito instigante e instrutiva. Ma'an deve ser agradecido de forma mais geral por nossa conversa contínua sobre a ética de dar e receber testemunho no país de chegada. Tive a sorte de estar em sua equipe para a produção de Newcomers (2018), um filme que dá voz a testemunhas que agora vivem na Alemanha. Nossos projetos conjuntos inspiraram muitos dos pensamentos e observações deste artigo, embora, é claro, eu seja o único culpado pelos erros que cometi. Por último, mas não menos importante, para comentários e discussão, gostaria de agradecer a Yahya Al-Abdullah, Melanie Altanian, Monika Betzler, Christine Bratu, Sam Durrant, Anca Gheaus, Hilkje Hänel, Jan-Christoph Heilinger, Sara Höweler, Amahl Khouri, James Camien McGuiggan, Isabel Kaeslin, Natasha McKeever, Corinna Mieth, Ameen Nasir, Maria Neunteufel, Konrad Siller, Joe Saunders, Martin Adesivo, Michaela Rehm, Ahmed Saleh, Anna Wehofsits, Verina Wild e Kerri Woods. 
nytimes.com/2018/02/02/world/middleeast/syria-torture-artist-najah-al-bukai.html

Améry, Jean (1980) At the Mind's Limits - Contemplations by a Survivor on Auschwitz and its Realities, traduzido por Sidney Rosenfeld e Stella P. Rosenfeld, Indiana University Press

Amnesty International (2015) "Between Prison and the Grave - Enforced Disappearances in Syria", disponível em: https://www.amnesty. org/download/Documents/MDE2425792015ENGLISH.PDF

Le Caisne, Garance (2015) Opération César - Au cœur de la machine de mort syrienne de la machine de mort syrienne, Paris: Editions Stock

Connolly, Kate (2019) "Germany arrests two Syrians suspected of crimes against humanity", in The Guardian, Feb. $13^{\text {th }}$, URL: https://www.theguardian.com/world/2019/feb/13/ germany-arrests-two-suspected-syrian-secret-service-officers

Dotson, Kristie (2011) "Tracking Epistemic Violence, Tracking Practices of Silencing", in: Hypatia, Vol. 26, No. 2, pp. 236-257

Eid, Kassam (2018) My Country - A Syrian Memoir, Bloomsbury Publishing

Frankfurt, Harry (1982) "The importance of what we care about", in: Synthese, No. 53, pp. 257-272

Fricker, Miranda (2007) Epistemic Injustice - Power and the Ethics of Knowing, Oxford University Press

Grahle, André (MS), “Two Levels of Solidarity: Witnessing Relationships and Responsibility to Act"

Grahle, André (2019) "Admiration as normative support", in: Archer, Alfred; Grahle, André, The Moral Psychology of Admiration, London/ New York: Rowman \& Littlefield International

Grahle, André (2017) "Gerechtigkeit für Syrien”, in: Joachim Helfer, Marco Meyer, Klaus Wettig (eds.) Wenn ich mir etwas wünschen dürfte: Intellektuelle zur Bundestagswahl 2017, Göttingen: Steidl Verlag, pp. $71-80$

al-Haj Saleh, Yassin (2017) Impossible Revolution - Making Sense of the Syrian Tragedy, London: Hurst Publishers

Hisham, Marwan; Crabapple, Molly (2018) Brothers of the Gun: A Memoir of the Syrian War, New York: One World

Independent International Commission of Inquiry on the Syrian Arab Republic (2018a) "Sieges as a weapon of war - encircle, starve, surrender, evacuate", disponível em: https://www.ohchr.org/Documents/ HRBodies/HRCouncil/CoISyria/PolicyPaperSieges_29May2018.pdf

Independent International Commission of Inquiry on the Syrian Arab Republic (2018b) "I lost my dignity": Sexual and gender-based violence 
in the Syrian Arab Republic", disponível em: https://www.ohchr.org/ Documents/HRBodies/HRCouncil/CoISyria/A-HRC-37-CRP-3.pdf

Kaleck, Wolfgang; Kroker, Patrick (2018) "Syrian Torture Investigations in Germany and Beyond - Breathing New Life into Universal Jurisdiction in Europe?", in: Journal of International Criminal Justice, No. 16, pp. 165-191

Langton, Rae (1993) "Speech acts and unspeakable acts", in: Philosophy \& Public Affairs, Vol. 22, No. 4, pp. 293-330

Laub, Dori (1992) "An Event Without A Witness: Truth, Testimony, and Survival", in: Felman, Shoshana; Laub, Dori, Testimony - Crises of Witnessing in Literature, Psychoanalysis and History, pp. 75-92

Levi, Primo (2001) The Voice of Memory - Interviews 1961-1987, editado por Marco Belpoliti and Robert Gordon, translated by Robert Gordon, Polity Press

Marcus, Dorothea (2016a) "Ratlosigkeit des Überlebens", in: die tageszeitung, April 8, available from http://www.taz.de/!5293536/

Marcus, Dorothea (2016b) "Weg vom Leidens-Porno", Goethe-Institut, disponível em: https://www.goethe.de/ins/my/de/kul/ mag/20824640.html

Margalit, Avishai (2002) The Ethics of Memory, Harvard University Press

Meiborg, Mounia (2016) "Mann, ich bin Flüchtling", in: Süddeutsche Zeitung, April 6, disponível em: https://www.sueddeutsche.de/kultur/ portraet-mann-ich-bin-fluechtling-1.2936855

Oliver, Kelly (2001) Witnessing: Beyond Recognition, University of Minnesota Press

Pearlman, Wendy (2017) We Crossed a Bridge and It Trembled: Voices from Syria, New York: Costum House

Schmitt, Uwe (2016) "Wütend-poetisches Stück über Syriens ermordete Träume", in: Die Welt, Jan. 23th, disponível em: https://www. welt.de/kultur/theater/article151376242/Wuetend-poetisches-Stueck-ueber-Syriens-ermordete-Traeume.html

UNCHCR (2015) "Global Trends - Forced Displacement in 2005", disponível em: http://www.unhcr.org/576408cd7

United Nations, Human Rights Council (2016) "Out of Sight, Out of Mind: Deaths in Detention in the Syrian Arab Republic", A/HRC/31/ CRP.1, disponivel em: https://www.ohchrorg/Documents/HRBodies/ HRCouncil/CoISyria/A-HRC-31-CRP1_en.pdf

Walker, Margaret Urban (2006) Moral Repair - Reconstructing Moral Relations after Wrongdoing, Oxford University Press

Yazbek, Samar (2015) Die gestohlene Revolution - Reise in mein zerstörtes Syrien, übers. v. Larissa Bender, Zürich: Verlag Nagel \& Kimche AG 
